\title{
Historic Caddo Archaeology: An Occasional Meeting of the East Texas Caddo Research Group, December 2-3, 2006, in Nacogdoches Texas
}

Timothy K. Perttula

Heritage Research Center, Stephen F. Austin State University

Tom Middlebrook

Heritage Research Center, Stephen F. Austin State University

Follow this and additional works at: https://scholarworks.sfasu.edu/ita

Part of the American Material Culture Commons, Archaeological Anthropology Commons, Environmental Studies Commons, Other American Studies Commons, Other Arts and Humanities Commons, Other History of Art, Architecture, and Archaeology Commons, and the United States History Commons

Tell us how this article helped you.

This Article is brought to you for free and open access by the Center for Regional Heritage Research at SFA ScholarWorks. It has been accepted for inclusion in Index of Texas Archaeology: Open Access Gray Literature from the Lone Star State by an authorized editor of SFA ScholarWorks. For more information, please contact cdsscholarworks@sfasu.edu. 
Historic Caddo Archaeology: An Occasional Meeting of the East Texas Caddo Research Group, December 2-3, 2006, in Nacogdoches Texas

\section{Creative Commons License}

\section{(c) (1) (8)}

This work is licensed under a Creative Commons Attribution-NonCommercial 4.0 International License 


\section{HISTORIC CADDO ARCHAEOLOGY: AN OCCASIONAL MEETING OF THE EAST TEXAS CADDO RESEARCH GROUP, DECEMBER 2-3, 2006, IN NACOGDOCHES, TEXAS}

\section{Timothy K. Perttula and Tom Middlebrook}

The articles in this issue of the Journal of Northeast Texas Archaeology had their origins in a meeting held in December 2006 of the East Texas Caddo Research Group (ETCRG). The meeting of archaeologists was held on December 2 and 3, 2006 at the Arthur Temple College of Forestry and Agriculture on the campus of Stephen F. Austin State University in Nacogdoches, Texas.

The ETCRG is an informal group of individuals interested in advancing the general understanding of Caddo archaeology in the East Texas region, and we have attempted to do this by convening meetings at various times to discuss pertinent and current problems and research issues concerning East Texas Caddo archaeology. The group has met several times between 1996 and 1999, and our most productive sessions dealt with a specific topic: namely, new understandings of the Middle Caddo period (ca. A.D. 1200-1400) (Middlebrook and Perttula 1997).

After a considerable hiatus, the ETCRG met again in 2006 to discuss the historic archaeology of the Caddo in East Texas. Specifically, this focus was chosen to encourage the consideration and development of a better regional understanding of the Caddo archaeological record in East Texas (Figure 1) following European contact (in its broadest sense, after ca. A.D. 1542) in light of recent findings and ongoing archaeological research. People invited to the ETCRG meeting were individuals that have a direct familiarity with historic Caddo sites in East Texas (see Appendix). These individuals were encouraged to come to the ETCRG to discuss some aspect of East Texas historic Caddo archaeology, bringing maps, photographs, illustrative artifacts, and other materials. From these presentations, ETCRG members had an open round table discussion where information was shared and archaeological questions and problems posed and further considered by the group as a whole. 


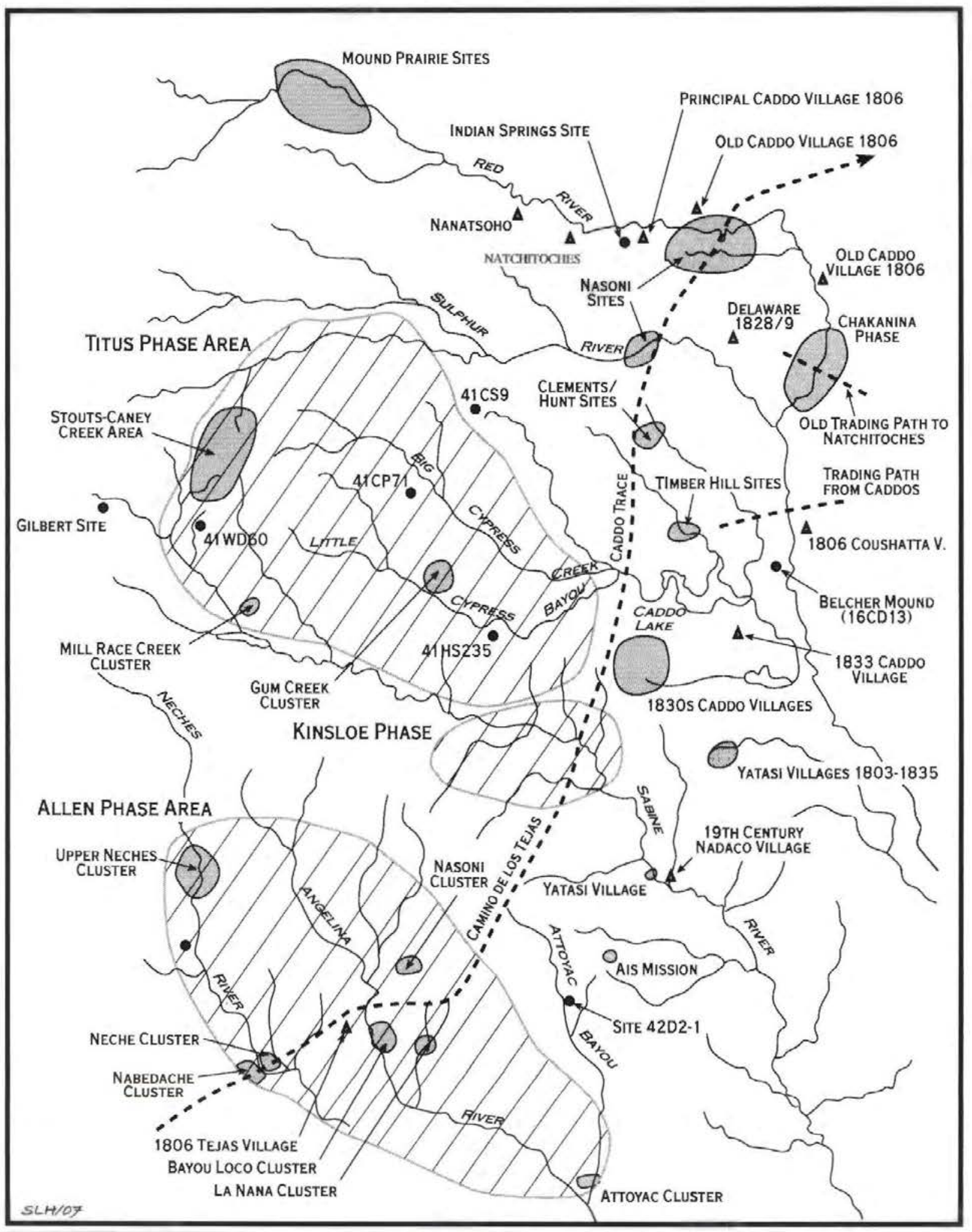

Figure 1. Map of East Texas showing relevant Historic Caddo sites and archaeological phases, as well as the general locations of some villages mentioned in historic documents and maps. 
The 2006 ETCRG meeting was wide-ranging and varied, as well as intellectually stimulating. Most of the discussions focused on particular Historic Caddo archaeological sites and their general material culture character, but the meeting ended with questions concerning future directions in the study of the Historic Caddo archaeological record.

After a general introduction and welcome, Timothy K. Perttula began this ETCRG meeting with some broad points of discussion concerning Historic Caddo archaeology, here in East Texas as well as in adjoining states. He ended with some suggestions on directions that may be productive to follow in the future to better understand the historic Caddo archaeological record.

Next, Tom Middlebrook provided a very detailed overview of what is known archaeologically about Historic Caddo and possible Historic Caddo archaeological sites in Nacogdoches County, Texas. At the present time, there are 29 sites known in the county, although they do not include either the two missions (Concepcion and Guadalupe) or presidio (Dolores) established by the Spanish in the first quarter of the $18^{\text {th }}$ century amongst Hasinai Caddo groups. These sites have not yet been identified archaeologically.

Various attempts have been made to employ ceramic analysis to group Caddo sites together, either grouping them on the basis of temporal indicators or on the basis of stylistic attributes that would suggest groups of contemporaneous Caddo sites are part of the same community of Caddo peoples (see Corbin, this volume). Perttula discussed several examples of such attempts with regard to Allen phase sites (dating after ca. A.D. 1650) - and the temporal and cultural relationship of the Frankston phase (ca. A.D. 14001650 ) to the succeeding Allen phase. Kleinschmidt's (1982) seriation work with vessels was first reviewed, followed by a proposed seriation of Caddo sites in the upper Neches River basin based on certain characteristics of Frankston and Allen phase sherd assemblages. Lastly, Perttula put forth an attempt to group historic Caddo archaeological sites in the Neches and Angelina River basins into clusters of related sites (subclusters in the Story and Creel [1982] schema], and possibly related Caddo peoples. This attempt drew heavily on the efforts of the late James E. Corbin (this volume).

Victor Galan followed with a review of the archaeological character of the Spradley site (41NA206) on LaNana Creek. Several Stephen F. Austin State University field schools have been held at this $18^{\text {th }}$ century Caddo site, but the results of that work have yet to be published. Hopefully that can be accomplished in the next few years, so that archaeological information from this important Historic Caddo site will be available to interested researchers.

Robert Turner provided a discussion of findings from another Historic Caddo site in Nacogdoches County: the Stevens site (41NA202) along the headwaters of Bayou Loco. This $18^{\text {th }}$ century site has a large assemblage of European glass beads $(n=7580)$ from a burial context, along with two Natchitoches Engraved vessels, a plain bottle, and a small assortment of sherds. The beads are dominated by small seed/drawn varieties of 
various colors, with very few large beads, suggesting the Caddo occupation here dates after ca. A.D. 1720-1740 (cf. Perttula 2005: Table 2).

Jeffrey $M$. Williams presented a very interesting review of $18^{\text {th }}$ century roads and trails in the southern part of East Texas, focusing on the El Camino Real. His presentation relied on GIS-aided archaeological and historical research to locate and identify $18^{\text {th }}$ century Spanish roads throughout the region as well as historic river and stream crossings. Knowing the road systems that existed at the time of the Historic Caddo settlement of East Texas allows archaeologists to better appreciate, and understand changes through time in, the distribution and organization of those settlements across the region, particularly since the main Spanish roads basically followed ancient Caddo traces.

The next presentation was by Shawn Marceaux. His discussion focused on a review of his dissertation research at The University of Texas at Austin. That research is concerned with the archaeology of the Hasinai Caddo groups in the Neches and Angelina River basins in East Texas. Much of his research effort will focus on a detailed study of the ceramic assemblages from known Historic Caddo sites in this area to better identify constituent and affiliated groups (cf. Story and Creel 1982) in the regional archaeological record.

Stepping out of East Texas (although still within the boundaries of $18^{\text {th }}$ century Spanish Texas) was a presentation by George Avery on the use of aboriginal pottery to identify Historic period sites in northwestern Louisiana. This presentation was based on a paper prepared by Gregory and Avery (2006). Avery's discussion included Natchitoches Engraved vessels and vessel sherds from sites such as Fish Hatchery (16NA9), Lawton Gin (16NA13) and Los Adaes (16NA16); Patton Engraved from Los Adaes; an unusual decorated style of Womack Engraved from Los Adaes; Ebarb Incised from Los Adaes; a variety of Emory Punctated-Incised (with bulging rims) from Los Adaes and Southern Compress (16NA14); and various shell-tempered plain wares from Los Adaes and the Procello site (I6DS212). Other kinds of ceramics found at Los Adaes includes Fatherland Incised and Chickachae Combed. There are also plain wares (pitchers, cups, and brimmed plates) from Fish Hatchery, Los Adaes, and Colfax Ferry (16NA15) that testify to a European influence on aboriginal ceramic vessel traditions. Avery also noted thst prior to ca. A.D. 1740 , bone-tempered ceramics were more commonly made in this area by aboriginal peoples, with a switch to shell-tempered ceramics after A.D. 1740.

The meeting returned to East Texas in Mark Walters' discussion of archaeological findings from Caddo sites along Caney Creek in Wood County, Texas. Collections amassed by his father in the 1960 s indicate that there are protohistoric (ca. 16701700/1720) Caddo settlements in this part of East Texas - as there are along Stouts Creek to the north (see Figure 1, see also Scurlock [1962] and Perttula and Green [2006]). One group of distinctive vessels from these protohistoric Caddo sites resemble Taylor Engraved, Wornack Engraved, and Ripley Engraved in terms of decorative style, but the vessel form is a globular carinated bowl with an inverted rim. There are also Simms Engraved and Keno Trailed vessels from the same ceramic assemblages. 
Jeff Girard discussed the archaeological evidence for historic Native American settlement in northern Louisiana, relying primarily on the kinds of pottery found throughout the region from the late $17^{\text {th }}$ century to the early part of the $19^{\text {th }}$ century. With respect to the Caddo living in this area, there are numerous sites in the Natchitoches area associated with the settlements of the Natchitoches Caddo, as well as other sites along the Red River and tributaries that may relate to the Doustioni, Adaes, Yatasi, and Nakasas Caddo. Girard also noted possible temporal changes in the use of brushed and ridged utility ware ceramic vessels as well as trailed fine wares from Late Caddo to protohistoric and early historic Caddo sites. One kind of Caddo site seen in northwestern Louisiana that has not been reported from East Texas is the salt-making site. These include sites such as Drakes Lick (16NA11) and Potters Pond (16WE76).

The ETCRG meeting wound down with a discussion of future directions in Caddo historic archaeology. All participants agreed that a broad-based Caddo archaeological database needs to be developed, and the compiled information shared through a cyberinfrastructure clearinghouse. Such a database could include separate but interlinked sections on sites in defined regions; ceramic assemblages (including whole vessels, sherds, and special analyses on ceramics [such as instrumental neutron activation analysis]); ceramic pipes; structures; mounds; radiocarbon, OCR, and TL dates; subsistence analysis; burials and mortuary analysis (including bioarchaeological studies); and relevant paleoenvironmental data (tree rings, isotopes; pollen, etc.). Although all agreed that such a database was desperately needed, there appear to be several ways to make that happen, all dependent upon financial resources, database construction expertise, and the willingness to share Caddo archaeological information. More discussion on this topic is envisioned for the $49^{\text {th }}$ Caddo Conference in Magnolia, Arkansas (March 2007).

We ended the successful ETCRG meeting on Historic Caddo archaeology with a consideration of possible future directions and research needs in the study of this period. They included:

(a) a need to define distinct ceramic assemblages that characterize Historic Caddo groups (basing them on 4-5 key attributes);

(b) how do we identify Historic Caddo sites in the absence of artifacts of European derivation? Related to that, how do we identify Historic Caddo sites dating to the early-mid-19 $9^{\text {th }}$ century when aboriginal Caddo pottery may be absent or scarce?;

(c) we need a better understanding of Caddo subsistence during this period, especially the effects on subsistence arising from the Caddo's participation in the deer hide trade, and their later adoption of European food products;

(d) there is a critical need to find post-1840 removal Caddo sites along the Trinity and Brazos rivers in north central Texas, as well as post-1859 Caddo archaeological sites in Oklahoma;

(e) a more systematic effort should be made to integrate the use of archival resources (maps and documents) in the study of the Caddo Historic archaeological record, along with the ability to work more closely with historians (see Smith 2005) and geographers interested in the history and geography of late $17^{\text {th }}$-mid- $19^{\text {th }}$ century Texas; and finally, 
(f) all of this effort should be brought to bear to provide a new and broader perspective on the effects of interaction between Europeans and the Caddo peoples as seen in the archaeological and historical records.

This issue of the Journal of Northeast Texas Archaeology contains written versions of some of the presentations given at the ETCRG, as well as other articles on various aspects of the historic Caddo settlement and religious ceremonies in East Texas and Oklahoma. We believe they provide important and new information on various aspects of East Texas Historic Caddo archaeology, as well as Historic Caddo archaeology in general, and we are pleased to see them published and this information made available to others interested in the archaeology of the Caddo peoples. Plans are afoot to convene another ETCRG meeting in late 2007 to continue with further discussions concerning historic Caddo archaeology in East Texas.

\section{References Cited}

Gregory, H. F. and G. Avery

2006 Using American Indian Pottery to Identify Historic Period Sites in Northwest Louisiana. Paper presented at the Annual Meeting of the Louisiana Archaeological Society, Monroe, Louisiana.

Kleinschmidt, U. K. W.

1982 Review and Analysis of the A. C. Saunders Site, 41AN19, Anderson County, Texas. Master's thesis, Department of Anthropology, The University of Texas at Austin.

Middlebrook, T. and T. K. Perttula

1997 The Middle Caddoan Period in East Texas: A Summary of the Findings of the East Texas Caddoan Research Group. Journal of Northeast Texas Archaeology 9:1-8.

Perttula, T. K., with contributions by T. E. Emerson and R. E. Hughes

200541 HO64/41HO65, Late $17^{\text {th }}$ to Early $18^{\text {th }}$ Century Caddo Sites on San Pedro Creek in Houston County, Texas. Bulletin of the Texas Archeological Society 75:85-103.

Perttula, T. K. and L. Green

2006 Marine Shell Ear Disks from Protohistoric Caddo Sites on Stouts Creek, Hopkins County, Texas. Journal of Northeast Texas Archaeology 25:19-25.

Scurlock, J. D.

1962 The Culpepper Site: A Late Fulton Aspect Site in Northeastern Texas. Bulletin of the Texas Archeological Society 32:285-316. 
Smith, F. T.

2005 From Dominance to Disappearance: The Indians of Texas and the Near Soulhwest, 1786-1859. University of Nebraska Press, Lincoln.

Story, D. A. and D. G. Creel

1982 The Cultural Setting. In The Deshazo Site, Nacogdoches County, Texas, Vol. 1: The Site, Its Selting, Investigations, Cultural Features, Artifacts of Non-Native Manufacture, and Subsistence Remains, edited by D. A. Story, pp. 20-34. Texas Antiquities Permit Series No. 7. Texas Antiquities Committee, Austin.

\section{Appendix, List of Participants at the 2006 ETCRG Meeting}

Tom Middlebrook

Mark Walters

Jeffrey M. Williams

Victor Galan

David Jeane
Timothy K. Perttula

Shawn Marceaux

Jay Blaine

Robert Turner
Bo Nelson

George Avery

Jeff Girard

Maynard B. Cliff 